\title{
FARMERS' ACCEPTANCE OF INSECTS AS AN ALTERNATIVE PROTEIN SOURCE IN POULTRY FEEDS
}

\author{
C. Sebatta1*, G. Ssepuuya1, E. Sikahwa1, J. Mugisha1, G. Diiro1, \\ M. Sengendo' ${ }^{2}$, P. Fuuna ${ }^{2}$, K.K.M. Fiaboe ${ }^{3}$ and D. Nakimbugwe ${ }^{1}$
}

Received 7 September 2018, Revised 30 November 2018, Accepted 26 December 2018, Published online 31 December 2018

\begin{abstract}
The research aimed at assessing the perceptions and willingness of poultry farmers, feed traders and processors to use insects as a source of protein ingredient in poultry feed. The research used a cross-sectional design and a structured questionnaire to collect quantitative data from 287 poultry farmers and 71 feed traders from 3 culturally diverse regions in Uganda. The study findings revealed that majority of the farmers mixed their own poultry feed. Willingness to use insects in poultry feeds was expressed by over $70 \%$ of the farmers, feed traders and processors, indicating a strong potential demand for insect-based feeds. However, some poultry farmers doubted the possibility of acquiring insects (rearing/harvesting) in large enough quantities and the consumers' acceptance of poultry products from birds raised on insect-based feed. Nonetheless, there is a high potential for adoption of insects for use as poultry feed if they can be produced in sustainable quantities that ensure the viability of poultry farming and the feed processing businesses.
\end{abstract}

Keywords: Acceptance, Insect Feed, Poultry, Probit, Feed and Willingness to use

${ }^{1}$ College of Agricultural and Environmental Sciences, Makerere University, P.O. Box 7062, Kampala, Uganda

${ }^{2}$ College of Humanities and Social Sciences, Makerere University, P.O. Box 7062, Kampala Uganda

${ }^{3}$ International Centre of Insect Physiology and Ecology, P.O. Box 30772-00100, Nairobi, Kenya \& IITA-Cameroon, BP. 2008 (Messa), IRAD Main Road, Nkolbisson; Yaoundé, Cameroon

*Corresponding author's email: sebattac@gmail.com (C. Sebatta)

Cite this article as: Sebatta, C., Ssepuuya, G., Sikahwa, E., Mugisha, J., Diiro, G., Sengendo, M., Fuuna, P., Fiaboe, K.K.M. and Nakimbugwe, D. (2018). Farmers' acceptance of insects as an alternative protein source in poultry feeds. Int. J. Agril. Res. Innov. Tech. 18(2), 32-41.

\section{Introduction}

The annual global turnover and sale of commercial feed is estimated at US\$ 350 billion and needs to increase by $70 \%$ in order to feed the world population by 2050 (Van Huis et al., 2013). The increase is expected to be accompanied by the doubling of livestock production including poultry, according to the International Feed Industry Federation (IFIF) (Veldkamp et al., 2012). Therefore, the demand for poultry feed will double, further increasing the demand for protein ingredients such as soybeans, cotton seed cake and fish meal (Maurer et al., 2016). The growing scarcity of resources to produce the increasingly demanded protein feed ingredients has resulted in their prices doubling (Veldkamp et al., 2012). This has led to prohibitive costs of feed, which accounts for $60-75 \%$ of the production costs (Heft-Neal et al., 2008). On the other hand, availability of land for cultivation of soybean and other plant protein sources is diminishing globally, while marine overexploitation has continued to reduce the abundance of small pelagic forage fish from which fishmeal is mainly derived (Tacon and Metian, 2009). Continuing to rely on fishmeal and soybean as protein sources for animal feed production is therefore increasingly becoming unsustainable (Van Huis et al., 2013).

The use of insect meal as a replacement for the expensive fish, animal or plant protein ingredients in feeds is socially acceptable because, in nature, fish and poultry are known to eat insects, for instance in the free-range poultry rearing system. In addition, many insects have a higher protein content than conventional fish and soybean meals (Anand et al., 2008) and favourably compare in performance, with conventional protein sources at both partial and complete replacement of fish protein in poultry feed (Moreki et al., 2012).

The amino acid profiles of most insects' protein are also superior to those from plant protein sources (soy meal and cotton seed cake) used in 
poultry feed formulations (Ravindran and Blair, 1993; Bukkens, 2005). Since protein is the most expensive ingredient in poultry and other livestock diets, using insects is thus a viable option (Maurer et al., 2016; Niassy and Ekesi, 2016). Insects including grasshoppers, crickets, cockroaches, termites, stink bugs, cicadas, aphids, scale insects, psyllids, beetles, caterpillars, flies, fleas, bees and ants have been used as complementary feed sources for poultry in Asia and the Pacific (Ravindran and Blair, 1993). In Africa, the poultry reared under the free-range system eat insects as they roam around homes and gardens and sometimes farmers deliberately avail the insects to their poultry. In Northern Uganda, farmers feed their chicken on insects by, for instance, digging up ant hills to expose termites or inserting grass blades into anthills to collect the termites (Akullo et al., 2017).

However, insects have not yet been integrated into the commercial production of poultry feeds. Before introducing insects as a new ingredient, it is necessary to establish the current perceptions of the targeted processors, traders and poultry farmers. This is because farmers' perceptions of technology characteristics significantly affect their adoption decisions (Mbaka et al., 2008; Adesina and Baidu-Forson, 1995). This study, therefore, aimed at assessing poultry farmers', feed processors' and traders' acceptance of insects as an alternative protein source to fishmeal in poultry feed in Uganda.

\section{Materials and Methods}

Study design

This study was conducted in three culturally diverse regions in Uganda; the Central, Eastern and Northern where poultry farming is a key enterprise for supporting livelihoods and people have various food cultures. A total of 287 poultry farmers and 71 feed traders/processors were interviewed using a structured questionnaire. The questionnaire captured farmer gender, perceptions on using insects in feeds, inputs used, poultry business size and location with open and closed-ended questions. The questionnaire was piloted in the three regions through a reconnaissance survey to test its suitability. Both farmers and traders were randomly selected using a sampling frame obtained from the reconnaissance study. To be included in the study, poultry farmers had to have at least 50 broilers and/or hybrid layers, while small to medium-scale poultry feed processors had to have an annual feed capacity of above one tonne. Data obtained were analysed using IBM SPSS Statistics for Windows, Version 20.0 (Armonk, New York) and Stata statistical software version 13.

\section{Econometric model}

The study's theoretical model was based on the choice theory where an individual poultry farmer or feed trader faces a choice set with $K_{i}$ alternatives. If we assume that, the utility function for a given alternative $k$ consists of a systematic part $V_{i}$ and a stochastic part, $\boldsymbol{E}_{i}$ and assuming that the error terms are independently and identically distributed with scale parameter $U_{i}$. Given an additive utility function and the distributional assumptions on the error terms, the probability of a farmer or trader choosing alternative $k$ becomes;

$P\{k / K\}=\frac{\exp \left(u V_{i}\right)}{\sum_{j e} \exp \left(u V_{j}\right)}$

Willingness to pay or buy or adopt a new product or technology has been widely studied and modeled using the probit model and its various forms such as the single probit (Batte et al., 2007), ordered probit (Boccaletti and Moro, 2000) or a combination of probit and the ordered probit (Huang et al., 1999). Modelled as a binary problem, willingness to use insects in poultry feeds was stated as a categorical dependent variable $(\mathrm{Yes}=1, \mathrm{No}=0)$.

The underlying latent model could be specified as;

$$
\begin{aligned}
& y=\left\{\frac{1, y_{i}^{*}>0}{0, y_{i}^{*} \leq 0}\right. \\
& y_{i}^{*}=x_{i}^{\alpha} \alpha+\varepsilon_{i} .
\end{aligned}
$$

The empirical model was stated as;

$y_{i}=\alpha_{0}+\alpha_{1} x_{1}+\alpha_{2} x_{2}+\ldots+\alpha_{3} x_{3}+\varepsilon_{i}$

Where $\mathrm{y}_{\mathrm{i}}$ is a binary variable (Yes $=1, \mathrm{No}=0$ ) for poultry farmer's willingness to use insect-based feeds.
$\alpha_{0-13}$ are parameters to be estimated while
$x_{1-13}$ are independent variables (Table 1). 
Table 1. Variable definitions and sample statistics.

\begin{tabular}{|c|c|c|c|}
\hline Variable & Definition & Mean & $\begin{array}{l}\text { Standard } \\
\text { deviation }\end{array}$ \\
\hline $\begin{array}{l}\text { Willing to rear insect for feeding } \\
\text { poultry or selling to feed } \\
\text { processors (Yes=1, No=0). }\end{array}$ & $\begin{array}{l}\text { Farmer is willing to rear insects for own } \\
\text { farm feeding to poultry (dummy) }\end{array}$ & 0.67 & 0.47 \\
\hline $\begin{array}{l}\text { Willing to buy insect-based } \\
\text { poultry feeds (Yes }=1, \mathrm{No}=0 \text { ). }\end{array}$ & $\begin{array}{l}\text { Farmer accepts to buy poultry feeds that } \\
\text { have been mixed with insects as one of the } \\
\text { ingredients (dummy) }\end{array}$ & 0.85 & 0.35 \\
\hline Poultry farmer's sex & Farmer sex (dummy) & 0.58 & 0.49 \\
\hline Poultry farmers age & Age (years) & 41.05 & 15.09 \\
\hline $\begin{array}{l}\text { Distance to main feed source } \\
(\mathrm{km})\end{array}$ & $\begin{array}{l}\text { How far the feed seller is from the farmer } \\
(\mathrm{km})\end{array}$ & 2.92 & 2.58 \\
\hline Total number of chickens owned & Chicken flock size & 245.72 & 236.54 \\
\hline $\begin{array}{l}\text { Farmer keeps exotic chicken } \\
\text { under the intensive system } \\
(\mathrm{Yes}=1, \mathrm{No}=0)\end{array}$ & $\begin{array}{l}\text { Layers or broilers kept under intensive } \\
\text { poultry system (dummy) }\end{array}$ & 0.88 & 0.33 \\
\hline $\begin{array}{l}\text { Farmer uses own mixed feed } \\
(\mathrm{Yes}=1, \mathrm{No}=0)\end{array}$ & $\begin{array}{l}\text { Farmer mixes ingredients to make home } \\
\text { poultry feed (dummy) }\end{array}$ & 0.54 & 0.50 \\
\hline $\begin{array}{l}\text { Farmer aware of insects are feed } \\
\text { for poultry (Yes }=1, \mathrm{No}=0)\end{array}$ & $\begin{array}{l}\text { Farmer has knowledge of poultry feeding on } \\
\text { insects (dummy) }\end{array}$ & 0.95 & 0.22 \\
\hline $\begin{array}{l}\text { Frequency of feed price } \\
\text { fluctuation }\end{array}$ & $\begin{array}{l}\text { Number of times a year, poultry feeds } \\
\text { changed price }\end{array}$ & 2.32 & 2.33 \\
\hline $\begin{array}{l}\text { Quantity of Silver Fish in own } \\
\text { mixed feed (kg) }\end{array}$ & $\begin{array}{l}\text { Amount of silver fish (protein ingredient) in } \\
\text { own mixed poultry feed }\end{array}$ & 83.25 & 45.64 \\
\hline $\begin{array}{l}\text { Frequency of feed purchases } \\
\text { (Number of times per month) }\end{array}$ & $\begin{array}{l}\text { Number of times a month, a farmer buys } \\
\text { poultry feeds }\end{array}$ & 3.15 & 3.03 \\
\hline $\begin{array}{l}\text { Farmer believes insects are good } \\
\text { for feed }\end{array}$ & $\begin{array}{l}\text { Farmer trusts that insects can make good } \\
\text { feeds for poultry (dummy) }\end{array}$ & 0.80 & 0.40 \\
\hline $\begin{array}{l}\text { Availability of extension service } \\
\text { providers Yes }=1, \mathrm{No}=0 \text { ) }\end{array}$ & $\begin{array}{l}\text { Extension workers are available and } \\
\text { accessible to farmers (dummy) }\end{array}$ & 0.54 & 0.50 \\
\hline $\begin{array}{l}\text { Easy access to inputs (Yes }=1 \\
\text { No=0) }\end{array}$ & $\begin{array}{l}\text { Farmer has easy access to poultry inputs } \\
\text { (dummy) }\end{array}$ & 0.47 & 0.50 \\
\hline
\end{tabular}

\section{Results}

Characteristics of poultry farmers and poultry feed traders
The results indicated that majority of poultry farmers were males. Similarly, the majority of the feed traders and processors were males, comprising of $50 \%$ sole feed traders and $88 \%$ of feed processors and traders (Table 2).

Table 2. Characteristics of poultry farmer household heads.

\begin{tabular}{|c|c|c|c|c|c|c|}
\hline \multirow[t]{2}{*}{ Characteristic } & \multicolumn{4}{|c|}{ Poultry farmens (\%) } & \multicolumn{2}{|c|}{ Feed dealers (\%) } \\
\hline & $\begin{array}{c}\text { Total } \\
(\mathrm{n}=287)\end{array}$ & $\underset{(n=145)}{\text { Gulu }}$ & $\begin{array}{l}\text { Tororo } \\
(n=34)\end{array}$ & $\begin{array}{l}\text { Masaka } \\
(\mathrm{n}=108)\end{array}$ & $\begin{array}{l}\text { Sole feed seller } \\
\quad(n=46)\end{array}$ & $\begin{array}{c}\text { Feed seller \& } \\
\text { processor }(n=25)\end{array}$ \\
\hline \multicolumn{7}{|l|}{ Sex } \\
\hline Male & 75.09 & 74.29 & 88.24 & 71.96 & 50 & 88 \\
\hline \multicolumn{7}{|l|}{ Education level } \\
\hline Never in school & 4.93 & 6.29 & 0.00 & 4.67 & 5 & 0 \\
\hline Pre-school & 0.70 & 0.70 & 2.94 & 0.00 & - & - \\
\hline Primary school & 33.10 & 35.00 & 29.41 & 31.78 & 5 & 9 \\
\hline Secondary school & 34.15 & 27.97 & 41.18 & 40.19 & 63 & 39 \\
\hline Tertiary level & 22.89 & 25.87 & 17.65 & 20.56 & - & - \\
\hline Post-graduate & 4.23 & 4.20 & 8.82 & 2.80 & 26 & 52 \\
\hline \multicolumn{7}{|l|}{ Proprietorship } \\
\hline Sole & N/A & $\mathrm{N} / \mathrm{A}$ & N/A & N/A & 89 & 84 \\
\hline Partnership & N/A & N/A & N/A & N/A & 9 & 12 \\
\hline Private & N/A & $\mathrm{N} / \mathrm{A}$ & N/A & N/A & 2 & 4 \\
\hline
\end{tabular}

Poultry production systems and flock system, compared to $18 \%$ in the central and composition

Eastern parts of Uganda. Intensive poultry

Most of the poultry production was under freerange, semi-intensive and intensive systems, with both local and exotic breeds (Fig. 1). Northern Uganda had the highest percentage of farmers (31\%) rearing local chicken under the free-range rearing is practiced more in the Central and Northern regions of the country.

The majority of the local birds were kept under the semi-intensive system with an average flock size of 79 cocks and 25 hens. 


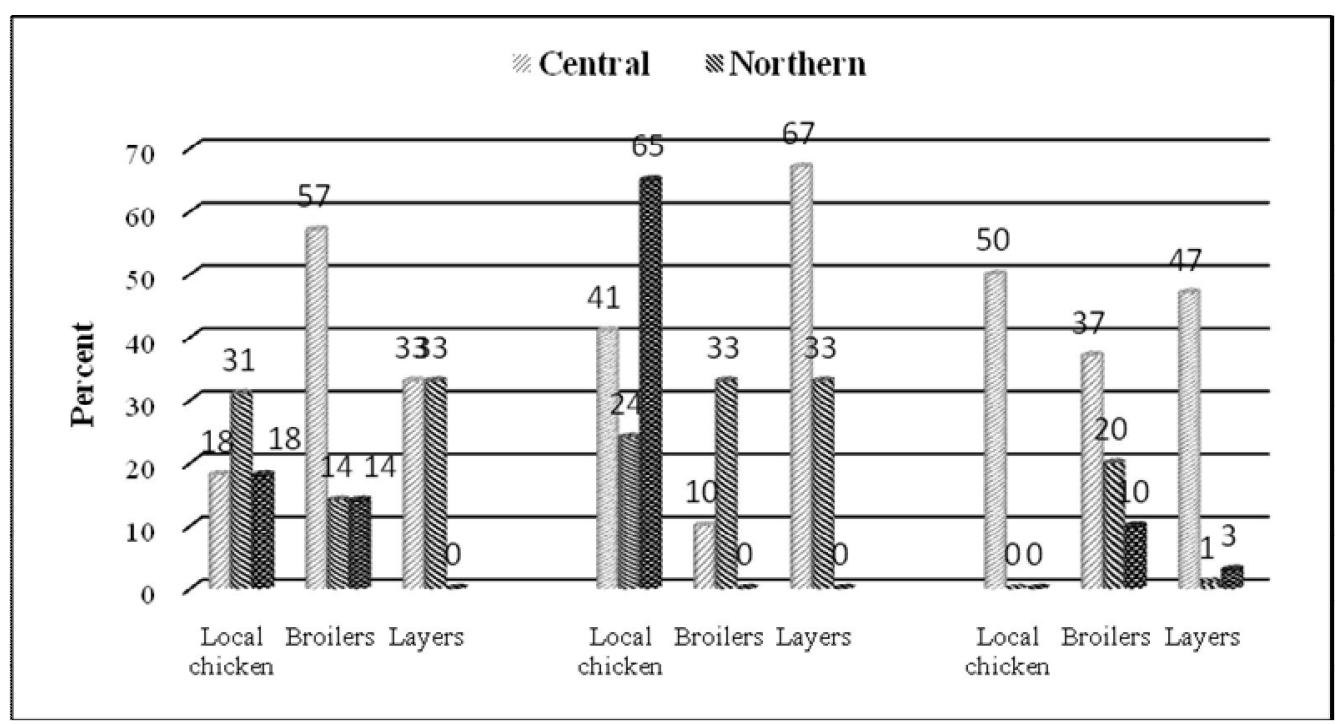

Fig. 1. Poultry farming systems practiced in Uganda by region.

Poultry feeds and feeding practices

More than half of the poultry farmers (53\%) used on-farm or own-mixed feeds. This was followed by grains $(34 \%)$, commercial feed $(28.8 \%)$, vegetables (16\%) and food remains (12\%). In the than females mixed their own feed. Consequently, more female than male farmers, used commercial feed. Use of food remains and vegetables as poultry feed was common among female farmers compared to their male counterparts (Fig. 2). central region, majority farmers used own-mixed feed (79\%) (Table 3). More male farmers (56\%)

Table 3. Main poultry Feeds used, by study site (\%).

\begin{tabular}{|l|cccc|} 
& & & Region $(\%)$ & \\
\hline Commercial feed & Pooled sample & Northern & Eastern & Central \\
\hline Own mixed feed & 28.85 & 51.06 & 57.14 & 16.67 \\
\hline Grains & 53.31 & 40.69 & 23.53 & 79.63 \\
\hline Food remains & 34.41 & 40.91 & 22.73 & 0.00 \\
\hline Vegetables & 12.90 & 15.15 & 4.55 & 20.00 \\
\hline
\end{tabular}

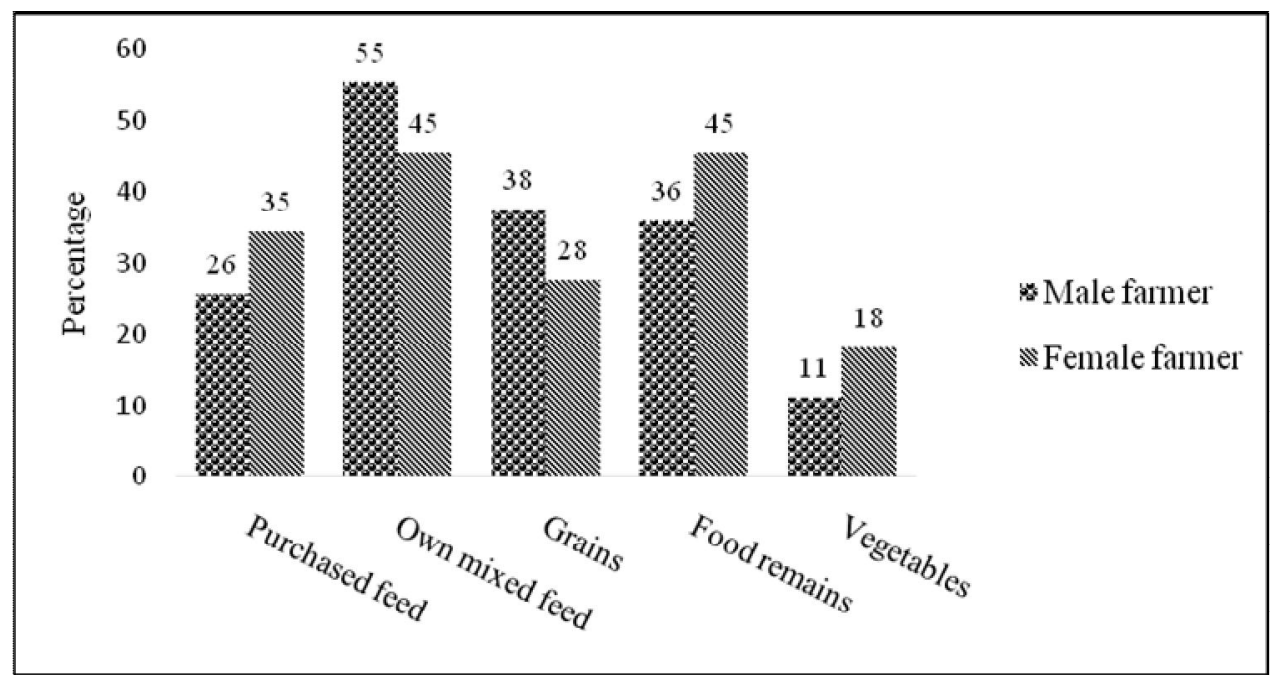

Fig. 2. Types of poultry feeds (\%) used by farmer's gender. 
Respondents' knowledge, attitudes and practices toward the use of insects

The majority ( $85 \%$ ) of the farmers were willing to buy insect-based poultry feeds (Fig. 3). Similarly, $84 \%$ of the traders and $83 \%$ of the processors believed that insects are good for poultry as feed. Farmers' age had a significant effect on the willingness to rear insects for feed (Table 4). Older farmers ( $42 \pm 15$ years) were more willing than the younger to rear insects. Farmers mixing larger quantities of feed were less willing to use insects than those mixing smaller quantities of feed (Table 3). Engagement in off-farm economic activities was negatively correlated with the willingness to buy insects for feed. From Table 3, $85 \%$ of the poultry farmers who were unwilling to buy insect-based feed were engaged in off-farm economic activities compared to $73 \%$ of the willing group.

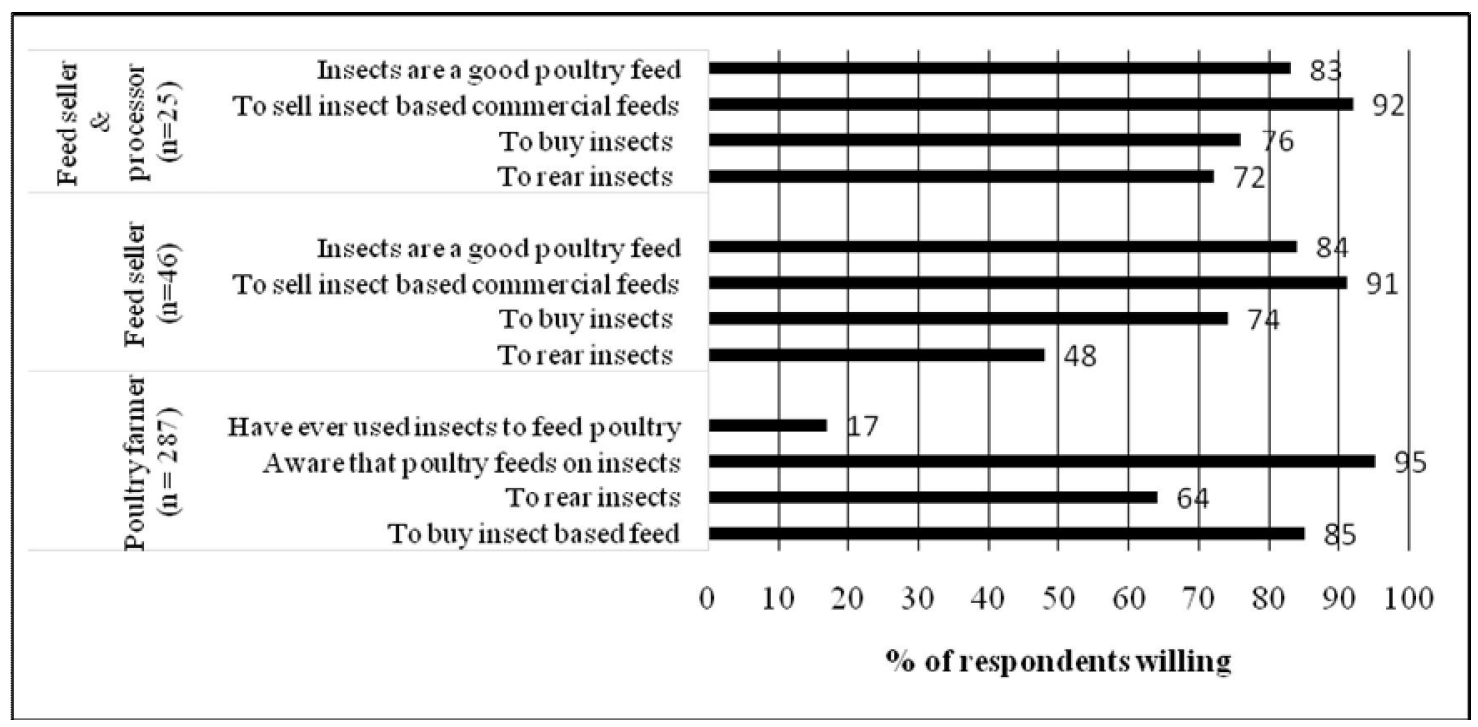

Fig. 3. Poultry Farmers' and feed traders' willing to rear and use insects in feeds.

Table 4. Characteristics of poultry farmers by willingness to buy insect-based poultry feeds.

\begin{tabular}{|c|c|c|c|c|}
\hline Variable & $\begin{array}{c}\text { Total } \\
(\mathrm{n}=287)\end{array}$ & $\begin{array}{l}\text { Willing } \\
(\mathrm{n}=225)\end{array}$ & $\begin{array}{l}\text { Un-willing } \\
(\mathrm{n}=62)\end{array}$ & \\
\hline & & Mean (SD) & & $\mathrm{P}$ value \\
\hline Farmer's age (years) & $41(15)$ & $42(15)$ & $36(14)$ & 0.02 \\
\hline $\begin{array}{l}\text { Quantity of silverfish (kg) in a weekly ration } \\
\text { of mixed poultry feed }\end{array}$ & $133(129)$ & $136(136)$ & $107(32)$ & 0.42 \\
\hline Quantity of weekly own mixed feed (kg) & $134(350)$ & $114(209)$ & $207(639)$ & 0.07 \\
\hline Frequency of buying feed (per month) & $4(5)$ & $4(5)$ & $3(2)$ & 0.20 \\
\hline & \multicolumn{4}{|c|}{ Percentages } \\
\hline Household is female-headed & 25 & 25 & 25 & 0.99 \\
\hline $\begin{array}{l}\text { Farmer believes insects can make good feed } \\
\text { ingredient }\end{array}$ & 80 & 87 & 45 & 0.00 \\
\hline $\begin{array}{l}\text { Farmer has engaged in off-farm business in } \\
\text { last } 12 \text { months }\end{array}$ & 76 & 73 & 85 & 0.05 \\
\hline $\begin{array}{l}\text { Farmer raised exotic chicken (Layers \& } \\
\text { broilers in last } 6 \text { months) }\end{array}$ & 61 & 60 & 63 & 0.68 \\
\hline Farmer uses mixed/purchased feeds & 66 & 63 & 74 & 0.10 \\
\hline
\end{tabular}

Besides the $14 \%$ of poultry farmers who did not thought that consumers may not accept poultry believe that insects could be a good protein products from birds raised on insect-based feed source, 33\% cited the fact that they had never while 20\% thought that insects could be difficult experienced or seen any insect-based feeds. The to harvest (Fig. 4). other $23 \%$ were concerned that insects were not easy to get in large enough quantities, $23 \%$ 


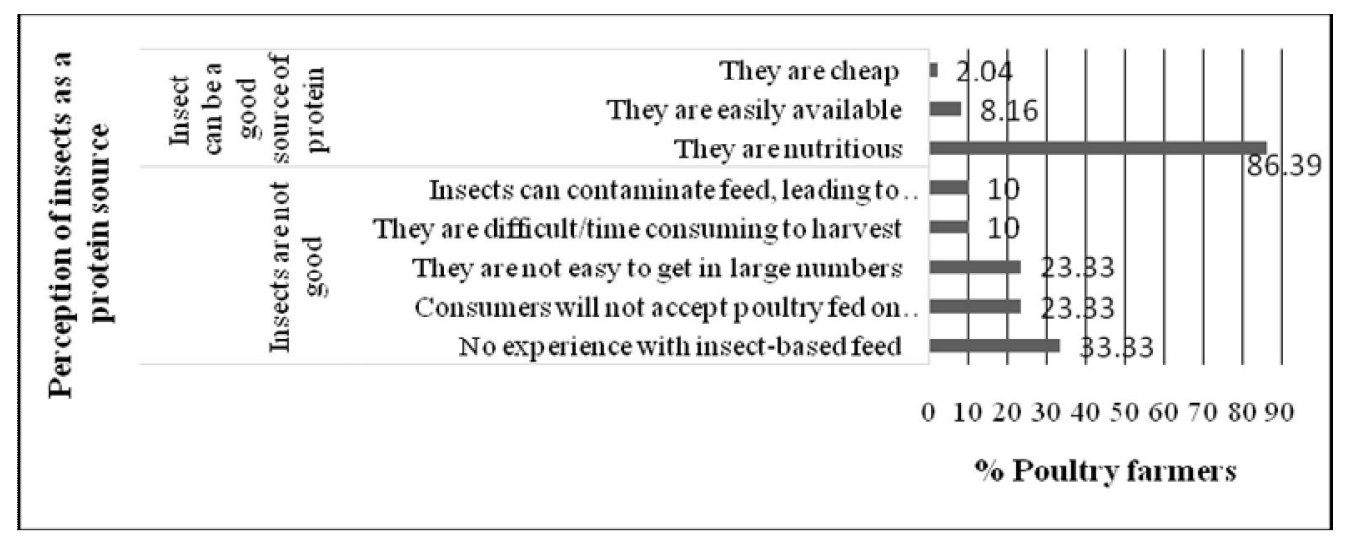

Fig. 4. Farmers' reasons for accepting insects as poultry feed.

Type of insects preferred by poultry farmers to rear and use for feeding poultry

Table 5 indicates that overall, the most preferred insects were grasshoppers (79\%), white ants (76\%), termites (62\%) and cockroaches (46\%). A similar trend was observed regionally with crickets added to the preference list in the central region.

Factors influencing farmers' willingness to rear and to use insects for poultry feed

Table 6 indicates that the probit model was able to predict willingness to rear by up to $67 \%$ and the willingness to buy by up to $81 \%$. Farmer awareness that poultry eats insects significantly reduced respondents' probability of expressing willingness to rear insects for poultry feed by 0.2 . The frequency of feed price fluctuation (number of times a farmer experienced price changes when

buying feeds in a year) significantly ( $\mathrm{p} \leq 0.05)$ reduced the probability of a farmer expressing willingness to rear insects for poultry feeds by 0.04 .

Keeping exotic chicken was found to significantly reduce the probability of willingness to buy the insect-based feeds by a factor of 0.16 (Table 6). Poultry farmer's age had a positive influence on their willingness to buy and use insects or insectbased feeds. Respondents' belief that insects can be good for their poultry significantly $(\mathrm{P} \leq 0.01)$ increased their willingness to rear insects. Farmers' belief that insects were good increased their probability of willingness to rear insects by 0.31 and their willingness to buy insect-based feed by 0.22 . Though not significant, availability of extension services, farmers mixing own feed and keeping exotic chicken among others increased the willingness to rear insects.

Table 5. Insects preferred by poultry farmers for rearing and use (\%).

\begin{tabular}{|lcccc|}
\hline Type of Insects & $\begin{array}{c}\text { Pooled Sample } \\
(\mathrm{n}=287)\end{array}$ & $\begin{array}{c}\text { Northern } \\
(\mathrm{n}=147)\end{array}$ & $\begin{array}{c}\text { Region } \\
\text { Eastern } \\
(\mathrm{n}=34)\end{array}$ & $\begin{array}{c}\text { Central } \\
(\mathrm{n}=106)\end{array}$ \\
\hline Cockroaches & 45.91 & 17.91 & 83.33 & 60.00 \\
\hline Housefly & 23.53 & 14.75 & 47.83 & 23.19 \\
\hline Termites & 61.68 & 53.42 & 80.00 & 63.77 \\
\hline WhiteAnts & 75.58 & 71.62 & 88.89 & 74.65 \\
\hline Beetles & 18.24 & 5.26 & 33.33 & 24.29 \\
\hline Crickets & 42.38 & 14.75 & 38.89 & 66.67 \\
\hline Grasshoppers & 79.12 & 72.29 & 92.31 & 82.19 \\
\hline Worms & 35.33 & 27.59 & 52.17 & 36.27 \\
\hline Black soldier flies & 18.31 & 3.70 & 30.00 & 26.47 \\
\hline Lake Flies & 15.49 & 0.00 & 30.00 & 23.19 \\
\hline YellowWorms & 15.60 & 0.00 & 40.00 & 20.29 \\
\hline SilkWorms & 18.62 & 3.77 & 52.17 & 18.84 \\
\hline Weevils & 13.24 & 0.00 & 15.00 & 23.44 \\
\hline
\end{tabular}


Table 6. Drivers of poultry farmers' willingness to rear and buy insects for feed.

\begin{tabular}{|c|c|c|c|c|}
\hline \multirow[t]{2}{*}{ Variables } & \multicolumn{2}{|c|}{ Willingness to rear insects } & \multicolumn{2}{|c|}{$\begin{array}{l}\text { Willingness to buy insect } \\
\text { based feeds }\end{array}$} \\
\hline & Coef. & Std. Err. & Coef. & Std. Err. \\
\hline Total number of chicken owned & $-7.0 e-05$ & $1.76 \mathrm{e}-04$ & 0.00 & 0.00 \\
\hline $\begin{array}{l}\text { Farmer keeps exotic chicken under the intensive } \\
\text { system (dummy) }\end{array}$ & -0.17 & 0.22 & $0.75^{* *}$ & 0.38 \\
\hline Farmer uses own mixed feed (dummy) & 0.23 & 0.17 & 0.27 & 0.23 \\
\hline Farmer aware of Insects are feed for poultry & $-0.24 *$ & 0.37 & $0.82^{* *}$ & 0.37 \\
\hline $\begin{array}{l}\text { Frequency of feed price fluctuation (times per } \\
\text { year) }\end{array}$ & $-0.06 * *$ & 0.05 & -0.03 & 0.08 \\
\hline $\begin{array}{l}\text { Farmer believes insects are good for feed } \\
\text { (dummy) }\end{array}$ & $0.62^{* * *}$ & 0.20 & $1.34^{* * *}$ & 0.25 \\
\hline Quantity of Silver Fish in own mixed feed (kg) & $2.4 \mathrm{e}+05$ & $7.9 e+05$ & 0.00 & 0.00 \\
\hline $\begin{array}{l}\text { Frequency of feed purchases (number of times per } \\
\text { month) }\end{array}$ & $3.9 \mathrm{e}+03$ & 0.02 & 0.01 & 0.03 \\
\hline Easy access to inputs (dummy) & 0.08 & 0.16 & -0.03 & 0.21 \\
\hline $\begin{array}{l}\text { Availability of extension service providers } \\
\text { (dummy) }\end{array}$ & 0.18 & 0.16 & -0.21 & 0.21 \\
\hline Farmer's sex (female $=1$ ) & -0.21 & 0.16 & 0.21 & 0.21 \\
\hline Farmers age & $0.01 * * *$ & 0.01 & $0.01^{* * *}$ & 0.01 \\
\hline Distance to main feed source (km) & $-4.2 \mathrm{e}-04$ & $2.8 \mathrm{e}-03$ & 0.01 & 0.01 \\
\hline cons & -0.42 & 0.45 & $-1.62^{* * *}$ & 0.53 \\
\hline Model summary & & & & \\
\hline Number of observations & 287 & & 287 & \\
\hline Wald $\operatorname{chi}^{2}(13)$ & 24.37 & & 53.22 & \\
\hline Prob > chi ${ }^{2}$ & 0.028 & & 0.00 & \\
\hline Pseudo R2 & 0.07 & & 0.24 & \\
\hline
\end{tabular}

Key:

Significancelevels: *10\%, **5\% and ***1\%:

a: $\mathrm{y}=\operatorname{Pr}$ (willing rear) (predict) $=0.672$

$\mathrm{b}: \mathrm{y}=\operatorname{Pr}$ (willing buy) (predict) $=0.812$

ND: Not determined

\section{Discussion}

\section{Demographic characteristics of poultry farmers and feed traders}

A gender analysis revealed that men dominated the poultry farming and feed processing and trading operations. This suggests that it is imperative to consider them in all interventions aimed at promoting the use of insects as feed. Men's dominance is not surprising though since research shows that men tend to be more involved in less laborious-more paying activities (Klapper and Parker, 2010).

In Uganda, increased participation of women in poultry management and marketing has been reported with no mention of the ownership of the poultry enterprises (IFAD, 2000; State et al., 2009). Therefore, it is possible that although men own the poultry farming enterprises, management is done by women (Doss et al., 2011). This implies that the involvement of men in an attempt to actualize the use of insects as poultry feed is crucial for successful adoption. Therefore at a small scale, the day-to-day management is most likely to be done by women who are less educated and less endowed with resources (Namatovu et al., 2016). However, with the relatively high literacy levels observed in this study, the delivery of extension messages and their adoption is likely to be relatively easy.

\section{Poultry production systems and flock composition}

The average flock size ( 79 cocks and 25 hens) in this survey was higher than the three cocks and six hens previously reported by Kugonza et al. (2008), indicating grouth in small-scale poultry farming businesses. This is also an indication that poultry farmers are moving towards commercializing the local and possibly improved kuroiler chicken breeds. Increased trends of using the intensive system to keep both local and improved poultry breeds are attributed to the high levels of urbanization that constrain farmers with smaller pieces of land and the necessity to intensify production systems (Atukunda et al., 2003). The same trend in central Uganda has been reported by Atukunda et al. (2003). Generally, farmers kept a large number of exotic birds (broilers and kuroilers) under the freerange system, especially in central Uganda (Fig. 1). In the central region, after six weeks of rearing the broilers indoors, some farmers fatten them by releasing them to scavenge outdoors for another three weeks with supplementary feeds, which reduces feed used and increases income from the birds (Emuron et al., 2010). This in part, explains the high number of broilers kept under the freerange system in the central region. 


\section{Poultry feeds and feeding practices}

The larger proportion of farmers using ownmixed poultry feeds relative to formulated feed is probably due to the high cost of and often poor quality formulated feed (Kasule et al., 2014; Xinhua, 2016) that falls short of meeting the birds' nutritional requirements (Nandudu, 2014). Farmers hence resort to mixing their own feed or feeding birds on vegetables and food remains in an effort to reduce costs and possibly ensure better quality of feeds. Use of cheaper feeds such as food remains and vegetables as feed was more common among female farmers compared to their male counterparts. This is possibly because women are more constrained owning and controlling fewer resources at the household level (Oluka et al., 2005; Smith et al., 2006).

For a farmer to be able to mix their own feed, they must have knowledge of the feed formulae for the type and age of poultry and have access to the ingredients used. However, Kasule et al. (2014) reported that farmers' own mixed feeds had less protein and metabolizable energy and higher amounts of dietary fibre compared to recommended poultry requirements. It is possible that farmers possibly have an idea about formulating feeds but limitations of the expertise, space, equipment and inability to adjust the feed formulation with ingredient nutritional quality among other factors could lead to the poor quality of the own formulated feed (Lukuyu et al., 2013; Musoke, 2015).

\section{Respondents' knowledge, attitudes and} practices toward the use of insects

The observed high degree of willingness among poultry farmers and poultry feed traders and processors could create demand and supply gaps if insects are not available in the required quantities. Noticeably, the percentage of poultry farmers willing to rear insects was lower than those willing to use them as poultry feed. This implies that non-poultry farmers could specialize in rearing and supplying insects to the feed traders and processors. Specialization maximizes output (Leonard, 2005) and therefore with specialized insect production, the much-desired quantities to meet the demand can be attained.

The positive attitude of the respondents can be attributed to the view that insects are nutritious, cheap and easily available for use as an ingredient in poultry feed (Fig. 3). Farmers' perceptions about new technologies can influence their adoption and views about those technologies (Mbaka et al., 2008; Adesina and Baidu-Forson, 1995). A positive perception, therefore, implies that farmers are most likely to adopt and use insect-based feed, which calls for paying careful attention to factors that may negatively influence this perception. Farmers' uncertainty over consumers acceptability of products from poultry raised on insect-based feed is real, as previously expressed by Duhaime-Ross (2016), Gareth (2014) and Kupferschmidt (2015) and requires adequate attention. Engagement in off-farm activities was a barrier to accepting the use of insects (Table 3). This is probably because the farmers with off-farm work get additional income and are not entirely dependent on poultry farming, so they were less concerned about costsaving alternatives such as insect-based feed.

\section{Insects preferred by poultry farmers to rear and use for feeding poultry}

Evidently, the majority of the insects the farmers were willing to rear and use are currently harvested from the wild and not intentionally reared. This implies that it is hard to be sure of the quantities and quality that can be obtained through insect harvesting. On the other hand, insects such as grasshoppers, white ants and termites are a human delicacy in Uganda and many parts of Africa, implying that even if rearing was successful, there would still be competition between animals and the humans as is the case for the local fish meal (Tacon and Metian, 2009). Hence, inedible insects should preferably be promoted to avoid such competition.

\section{Factors influencing farmers' willingness to rear and use insects for poultry feed}

Farmers' awareness that poultry feed on insects, the frequency of feed price fluctuation and rearing exotic birds on a commercial scale negatively influenced acceptability. Most farmers were keeping the poultry under the free-range system in which birds scavenge for insects and other foods without the farmers' deliberate efforts to collect the insects. Hence, farmers probably didn't feel the need to rare insects if the chickens freely hunt and eat them. The frequency of fluctuation of feed prices would be expected to translate into willingness by the farmer to take up new cost-saving and price stabilizing technologies such as insect-based feeds. However, this was not the case possibly because many commercial farmers are generally not easily convinced to change their poultry ration compositions for fear of the unknown outcomes and perception of consumers. Respondents rearing exotic chicken on either a semi-commercial or a fully commercial scale are not easily convinced to take up new technologies unless they have proven them, hence the negative marginal effect also reported in other studies (Guerin and Guerin, 1994; Daberkow and McBride, 2003; Marra et al., 2003).

On the other hand, farmers' belief that insects can be good for making poultry feeds and being older in age positively influenced their willingness to use insects for the poultry feeds. Older farmers have accumulated experience in rearing poultry and it is a family business they are not about to quit, hence, their willingness to find means to make it a more profitable venture. Feder et al. 
(1985) reported that farmer's beliefs and skills couple to determine their decision to take on a technology or not.

\section{Conclusions}

Poultry farmers, feed traders and processors were found to be willing to accept insects as an alternative protein source in poultry feed. Perception of insects as a good feed ingredient is mainly related to their nutritional value. Poultry farmers, feed traders and processors ranked the insects highly as having a high nutritional value among the qualities considered to rate insects as good fit for poultry rations. In addition, the type of insects one is willing to rear or use in feed formulation depends much on its availability in the community and prior exposure to such an insect. Keeping commercial breeds of poultry such as layers and broilers under intensive systems was found to drive farmers' willingness to buy insect-based poultry feed but had no effect on willingness to rear the insects. Therefore, developing insect-based feeds for poultry production is very likely to succeed and contribute to improved incomes and, food and nutritional security in Sub-Saharan Africa where those challenges have the highest impact.

\section{Recommendation}

This study reveals that the deliberate use of insects in poultry feeds is a new concept and like other innovations, faces adoption challenges that should be holistically addressed. This shall include but not limited to determining and addressing any negative perceptions of consumers towards poultry fed on insect-based feed and assuring poultry farmers and traders that accumulation of required quantities of insect material for commercial poultry rearing is possible.

\section{Acknowledgement}

We thank IDRC/ ACIAR for funding this research through the CultiAF research partnership under the Insect for Feeds (INSFEED) Project in Uganda and Kenya.

\section{References}

Adesina, A.A. and Baidu-Forson, J. 1995. Farmers' perceptions and adoption of new agricultural technology: evidence from the analysis in Burkina Faso and Guinea, West Africa. Agril. Econ. 13(1): 1-9.

Akullo, I., Obaa, B.B., Acai, I. .O., Nakimbuqwe, D. and Agea, J.G. 2017. Knowledge, attitudes and practices on edible insects in Lango subregion, northern Uganda. J. Insects as Food and Feed. 3(2) : 73-81. https:// doi.oro/ 10.3920/J IFF2016.0033.

Anand, H., Ganguly, A. and Haldar, P. 2008. Potential value of acridids as high protein supplement for poultry feed. Int. J. Poultry Sci. 7(7): 722-725.
Atukunda, G., Baseke, F., David, Soniia, Jagwe, J ohn, Kalyebara, M., Kaweesa, M., Miiro, R., Musoke, P., Nabulo, G., Namagembe, A., Niringiye, Charles, Nyapendi, R., Odongo, B., Owori, C., Azuba-Ssemwanga, M. and Tumwegamire, S. 2003. Farming in the city: participatory appraisal of urban and periurban agriculture in Kampala. Centro Internacional de Agricultura Tropical (CIAT), Kampala, UG. 39 p. (CIAT Africa occasional publications series no. 42). https:// hdl.handle.net/ 10568/ 72126.

Batte, M.T., Hooker, N.H., Haab, T.C. and Beaverson, J. 2007. Putting their money where their mouths are: Consumer willingness to pay for multi-ingredient, processed organic food products. Food Policy. 32(2): 145-159.

Boccaletti, S. and Moro, D. 2000. Consumer Willingness-To-Pay for GM Food Products in Italy. AgBioForum. 4 (3): 259-267.

Bukkens, S.G., 2005. Insects in the human diet: nutritional aspects. Ecological implications of minilivestock, CRC Press. pp. 545-577.

Daberkow, S.G. and McBride, W.D. 2003. Farm and operator characteristics affecting the awareness and adoption of precision agriculture technologies in the US. Precision Agric. 4(2): 163-177.

Doss, C., Deere, C.D., Oduro, A.D., Swaminathan, H., Suchitra, J.Y., Lahoti, R., Baah-Boateng, W., Boakye-Yiadom, L., Contreras, J., Twyman, J., Catanzarite, Z, Grown, C. and Hillesland, M. 2011. The Gender Asset and Wealth Gaps: Evidence from Ecuador, Ghana, and Karnataka, India. Bangalore: Indian Institute of Management Bangalore.

Duhaime-Ross, A. 2016. Your Meat Should Be Raised on Insects, U.N. Says - Scientific American Blog Network. Available at: https:// blogs.scientificamerican.com/observation s/your-meat-should-be-raised-on-insects-u-nsavs.

Emuron, N., Magala, H., Kyazze, F.B., Kugonza, D.R. and Kyarisiima, C.C., 2010. Factors Influencing the trade of local chickens in Kampala city markets. Livestock Res. Rural Dev. 22(4). Article \# 76. Retrieved J anuary 20, 2019,

from http:// www.lrrd.org/lrnd22/4/ emur22076.htm.

Feder, G., J ust, R.E. and Zilberman, D. 1985. Adoption of agricultural innovations in developing countries: A survey. Econ. Dev. Cultural Change. 33(2): 255-298.

Gareth, M. 2014. Animal Feed Made from Maggots Might Save the World MUNCHIES. Available at: https://munchies.vice.com/en_us/article/9agjx5 Lanimal-feed-made-from-maggots-might-savethe-world.

Guerin, L.J. and Guerin, T.F. 1994. Constraints to the adoption of innovations in agricultural research and environmental management: a review. Australian J. Expt. Agric. 34(4): 549-571. 
Heft-Neal, S., Otte, J., Pupphavessa, W., RolandHolst, D., Sudsawasd, S. and Zilberman, D., 2008. Supply chain auditing for poultry production in thailand. Bangkok, Thailand. $54 \mathrm{p}$.

Huang, C.L., Kan, K. and FU, T.T. 1999. Consumer Willinqness-to-Pay for Food Safety in Taiwan: A Binary-Ordinal Probit Model of Analysis. J. Consumer Affairs. 33(1): 76-91

IFAD. 2000. IFAD's Gender Strengthening Programme in Eastern and Southern Africa. Available at: https:// www.ifad.org/ documents/ 10180/ e866d6 29-8693-44d8-b01a-3481ab9b26f2.

Kasule, L., Katongole, C., Nambi-Kasozi, J., Lumu, R., Bareeba, F., Presto, M. Ivarsson, E. and Lindberq, .J.E. 2014. Low nutritive quality of own-mixed chicken rations in Kampala City, Uganda. Agron. Sustain. Dev. 34(4): 921-926.

Klapper, L.F. and Parker, S.C. 2010. Gender and the business environment for new firm creation. The World Bank Res. Obs. 26(2): 237-257.

Kugonza, D.R., Kyarisiima, C.C. and Iisa, A. 2008. Indigenous chicken flocks of Eastern Uqanda: Productivity, management and strategies for better performance. Livestock Res. Rural Dev. 20(9): 1-7.

Kupferschmidt, K. 2015. Feature: Why insects could be the ideal animal feed. Sci. Available at: https:// doi.ora/ 10.1126/ science.aad4709

Leonard, T.M. 2005. Encyclopedia of the developing world. Routledge. 2184p.

Lukuyu, B., Baker, D., Baltenweck, I., Poole, J., Kabi, F., Katongole, C. and Wabwire, R. 2013. The Concentrate feeds value chain in Uganda The Concentrate Feeds Supply chain in Uganda: emerging trends and implications on quality and access to smallholder farmers and chain efficiency A project report. Kampala. Available at: https:// cgspace.cgiar.org//bitstream/ handle/ 1056 8/34469/Concentrate Feeds Supply chain in Uqanda. pdf?sequence $=1$.

Marra, M., Pannell, D.J. and Ghadim, A.A. 2003. The economics of risk, uncertainty and learning in the adoption of new aqricultural technologies: where are we on the learning curve? Aaril. Svstems. 75(2): 215-234.

Maurer, V., Holinger, M., Amsler, Z., Früh, B., Wohlfahrt, J., Stamer, A. and Leiber, F. 2016. Replacement of soybean cake by Hermetia illucens meal in diets for layers. J. Insects as Food Feed. 2(2): 83-90.

Mbaka, J.N., Mwanqi, M. and Mwanqi, M.N. 2008. Banana farming as a business: The role of tissue cultured planting materials in Kenya. J. Appl. Biosci. 9(1): 354-361.

Moreki, J., Tiroesele, B., Chiripasi, S., 2012. Prospects of utilizing insects as alternative sources of protein in poultry diets in Botswana: a review. J. Anim. Sci. Adv. 2(8): 649-658.
Musoke, S. 2015. Poultry Feed Dilema - Mix My Own or Outsource? A Ugandan Farmer. Available

https:// ugfarmer.wordpress.com/2015/ 07/13/po ultry-feed-dilema-mix-my-own-or-outsource/

Namatovu, R., Langevang, T., Dawa, S. and Kyejjusa, S. 2016. Youth enterprenurship trends and policies in Uganda. pp. 19-32. In: K.V. Gough, and T. Langevang, Young Entrepreneurs in Sub-Saharan Africa (p. 292). Routledge Publishers, New York.

Nandudu, P. 2014. Parliament Told To Speed Up Law On Animal Feeds. Kampala. Available at:

http://www.newvision.co.ug/ new vision/ news/ 1 305855/ parliament-told-speed-law-animal-feeds.

Niassy, S. and Ekesi, S. 2016. Contribution to the knowledge of entomophagy in Africa. J. Insects as Food and Feed. 2(3): 137-138.

Oluka, J., Owoyesigire, B., Esenu, B. and Sssewannyana, E. 2005. Small stock and women in livestock production in the Teso Farming System region of Uganda. Available at:

https:// assets.publishing.service.gov.uk/media/ 5 7a08c1de5274a27b2000fb7/R8108d.pdf.

Ravindran, V. and Blair, R., 1993. Feed resources for poultry production in Asia and the Pacific region. I. Energy sources. Worlds Poult. Sci. J. 47 (3): 213- 231.

Smith, T., Godfrey, S., Buttery, P., Ssewannyana, E. and Owen, E. 2006. Small stock in development. p. 99. In: Proceedings of a workshop on enhancing the contribution of small livestock to the livelihoods of resourcepoor communities, Hotel Brovad, Masaka, Uganda.

State, A. E., Birungi, P. B. and De Haan, N. 2009. The role of poultry in peoples livelihoods in Uganda. Available at: http:// www.fao.org/docrep/ 013/al690e/ al690e0 0.pdf

Tacon, A.G.J. and Metian, M., 2009. Fishing for Aquaculture: Non-food use of small pelagic forage fish-a global perspective. Rev. Fish. Sci. 17: 305- 317.

Van Huis, A., Van Itterbeeck, .I., Klunder, H., Mertens, E., Halloran, A., Muir, G. and Vantomme, P. 2013. Edible insects: future prospects for food and feed security (No. 171). Food and aqriculture organization of the United nations (FAO). 187p.

Veldkamp, T., van Duinkerken, G., van Huis, A., lakemond, C., Ottevanger, E., Bosch, G. and van Boekel, M. 2012. Wageningen UR Livestock Research Partner in livestock innovations Insects as a sustainable feed ingredient in pig and poultry diets-a feasibility study. Wageningen, The Netherlands. $48 \mathrm{p}$.

Xinhua. 2016. Poultry World - Kenya: Farmers creating own feed due to rising costs. Nairobi. Available at: http://www.poultryworld.net/Nutrition/Articles/ 2015/3/Kenya-Farmers-creating-own-feed-dueto-rising-costs-1716476W. 